\section{Síndrome de Tonegawa}

\section{Tonegawa syndrome}

\section{Sr. Editor:}

Susumu Tonegawa nació en Nagoya, Japón, en 1939. Se licenció en bioquímica en la Universidad de Kyoto en 1963 y se doctoró en San Diego, California, en 1969. Fue en esta ciudad donde empezó a trabajar en el campo de la investigación, en el Instituto Salk, hasta que en 1971 se trasladó al Instituto de Inmunología de la empresa farmacéutica Hoffmann-La Roche, en Basilea (Suiza), donde conoció a Niels Jerne, futuro premio Nobel de Medicina en 1984 que le introdujo en el estudio de los anticuerpos. Diez años más tarde, en 1981, volvió a Estados Unidos de Norteamérica, para enseñar biología en el Instituto de Tecnología de Massachusetts (MIT), en calidad de catedrático.

Descubrió que ciertos elementos de la masa genética $(\mathrm{ADN})$ podían transferirse y reagruparse en el transcurso del desarrollo, al pasar de la célula embrionaria al estado del linfocito $\mathrm{B}$. Demostró que cada linfocito es capaz de formar el anticuerpo necesario, es decir, el anticuerpo que el organismo necesita en cada momento. Ante una agresión por un antígeno determinado se produce una respuesta celular del organismo y la recombinación adecuada de genes para formar el anticuerpo específico contra ese antígeno. Ante estos hallazgos Tonegawa llegó a formular la teoría de que la cantidad y calidad de la respuesta inmunitaria está condicionada genéticamente. Gracias a sus trabajos se ha podido conocer cuántos genes de inmunoglobulinas tiene el ser humano, y cómo dan lugar a multitud de anticuerpos específicos. Fue el primer japonés en recibir un premio Nobel de Fisiología o Medicina, en el año 1987, por sus investigaciones sobre el origen genético de los anticuerpos ${ }^{1}$.

Durante el año 2006 Tonegawa estuvo envuelto en un escándalo académico que lo obligó a renunciar a su cargo en el MIT: se comportó de manera reprochable con la Dra. Alla Karpova, antigua colaboradora suya, ya que impidió que trabajara en otro centro de investigación del MIT (McGovern Institute for Brain Research), donde tenia una oferta importante. De acuerdo con la información hecha pública, Karpova había recibido varios e-mails intimidatorios de Tonegawa ${ }^{2}$. Según Tonegawa, las investigaciones de ambos se superponían. Todo ello produjo que Karpova solicitara trabajo en otra universidad ${ }^{3}$.

La dirección del MIT creó una comisión para dirimir las responsabilidades de Tonegawa. La comisión se pronunció de manera tibia, ya que intentó defender la actitud de Tonegawa al verse de alguna manera amenazado por la Dra. Karpova, al quererse trasladar a otro centro del MIT. En cambio para Nancy Hopkins, bióloga del MIT, esta respuesta indecisa perpetúa la conducta destructiva de los administradores e investigadores seniors contra los jóvenes investigadores.

El caso Tonegawa ilustra el fracaso de algunos científicos como mentores de jóvenes investigadores. Cualquier sistema en el que los investigadores jefes puedan frenar el desarrollo de los investigadores en formación amenaza el futuro científico de los jóvenes más brillantes. Esto puede suceder en cualquier disciplina, porque por más renombrado que alguien pueda ser en el plano de la ciencia, no puede escapar a su "ser humano", al egoísmo, que es parte de nosotros mismos. Es obvio que como tales somos claramente imperfectos. Lo que sucede es que a medida que pasan los años muchos tratan de superar esos defectos, en tanto que otros no los advierten o insisten en ellos como si fueran algo natural. Este principio de autocrítica en la conducta personal no es muy frecuente en la vida de la gente.

Este caso puede extrapolarse a la medicina, dado el freno en el entrenamiento de jóvenes médicos ocasionado por médicos de mayor edad, quienes los ven como una competencia a futuro. No olvidemos que los mayores tenemos casi la obligación moral de impulsar el progreso y la superación de quienes nos suceden. Quienes cometen esa falta, al impedir o entorpecer el progreso y la superación de otros, no son maestros en el verdadero sentido de la palabra ${ }^{4}$. Olvidan además que sus logros, por óptimos que sean, son sólo verdades para hoy y, siguiendo a Karl Popper, ignoran que esas verdades de hoy contienen, en general, las falencias que permitirán acercarse a una "verdad más verdadera" el día de mañana. ¿Y quiénes conseguirán estos éxitos? Pues quienes nos sucedan. Es por ello que el deber de todo maestro es impulsar el progreso de quienes vienen detrás haciendo esfuerzos por la superación en todos los campos.

El científico es hombre antes que científico, y el hombre es conocido por su imperfección. Es por ello que quienes han alcanzado metas de 
importancia deben trabajar para que los demás también los superen. Es la forma de avanzar que tiene la humanidad.

Linazasoro propone llamar a la conducta mostrada por este científico, "síndrome de Tonegawa" Como se pregunta este autor ¿debería ser desposeído públicamente del premio Nobel? Este tipo de actitudes deshonran el espíritu y la grandeza de los premios.

Lo cierto es que ha habido en la historia gente carente de valores morales que, sin embargo, han triunfado en la ciencia o en cualquier campo del saber. A Tonegawa le podrán reprochar sus valores personales, pero no los científicos. Su premio Nobel no le fue entregado por sus principios éticos, sino por sus logros científicos.

Quizá siendo injusto, ya que no lo conozco personalmente, podría decir que Tonegawa padece de bronceosis, y es posible que esté orgulloso de que exista un síndrome con su nombre.

Pablo Young Servicio de Clínica Médica, Hospital Británico de Buenos Aires, Argentina.

\section{Referencias}

1. Shampo MA, Kyle RA, Steensma DP. Susumu TonegawaJapan's first Nobel laureate in Physiology or Medicine. Mayo Clin Proc 2011; 86: 14.

2. Lawler A. U.S. academic research. MIT report finds 'breakdown' in neuroscience programs. Science 2006; 314: 913

3. Lawler A. Controversy on the Brain. Science 2006; 314: 1227.

4. Semeniuk GB. De maestros y discípulos. Homenaje a Alfredo Lanari (1910-1985) Medicina (B. Aires) 2010; 70: 297-8.

5. Linazasoro G. Síndrome de Tonegawa. Neurología 2007; 22: 265.

6. Young P. Bronceosis: enfermedad especulativa por depósito de bronce. Rev Med Chile 2012; 140: 824-5.

Conflictos de intereses: el autor declara no tenerlos en este documento.

Correspondencia a:

Dr. Pablo Young. Hospital Británico. Perdriel 74 (1280) Buenos Aires, Argentina. Teléfono: 541143096400 Fax: 541143043393

E-mail: pabloyoung2003@yahoo.com.ar 